\title{
Up-dating the Cholodny method using PET films to sample microbial communities in soil
}

\author{
O. V. Moshynets, A. Koza', P. Dello Sterpaio', V. A. Kordium, A. J. Spiers ${ }^{1,2}$ \\ Institute of Molecular Biology and Genetics NAS of Ukraine \\ 150, Akademika Zabolotnoho St., Kyiv, Ukraine, 03680 \\ ${ }^{1}$ The SIMBIOS Centre, University of Abertay Dundee \\ Bell St., Dundee DD1 $1 \mathrm{HG}$, UK \\ ${ }^{2}$ Division of Forensics and Bio Sciences, School of Contemporary Sciences, University of Abertay Dundee \\ Bell St., Dundee DD1 1HG, UK \\ moshynets@gmail.com
}

\begin{abstract}
The aim of this work was to investigate the use of PET (polyethylene terephtalate) films as a modern development of Cholodny's glass slides, to enable microscopy and molecular-based analysis of soil communities where spatial detail at the scale of microbial habitats is essential to understand microbial associations and interactions in this complex environment. Methods. Classical microbiological methods; attachment assay; surface tension measurements; molecular techniques: DNA extraction, PCR; confocal laser scanning microscopy (CLSM); micro-focus X-ray computed tomography ( $\mu C T)$. Results. We first show, using the model soil and rhizosphere bacteria Pseudomonas fluorescens SBW25 and P. putida KT2440, that bacteria are able to attach and detach from PET films, and that pre-conditioning with a filtered soil suspension improved the levels of attachment. Bacteria attached to the films were viable and could develop substantial biofilms. PET films buried in soil were rapidly colonised by microorganisms which could be investigated by CLSM and recovered onto agar plates. Secondly, we demonstrate that $\mu C T$ can be used to non-destructively visualise soil aggregate contact points and pore spaces across the surface of PET films buried in soil. Conclusions. PET films are a successful development of Cholodny's glass slides and can be used to sample soil communities in which bacterial adherence, growth, biofilm and community development can be investigated. The use of these films with $\mu$ CT imaging in soil will enable a better understanding of soil micro-habitats and the spatially-explicit nature of microbial interactions in this complex environment.
\end{abstract}

Keywords: Pseudomonas, soil, buried slide, PET film.

Introduction. The complex interactions between microorganisms and their role in soil processes is fundamental to soil and plant health and productivity $[1,2]$. The last two decades have seen a significant development of molecular methods allowing the investigation of microbial diversity and activity in soils and the rhizosphere [3]. However, sampling methods largely ignore the spatial distribution of organisms within the complex 3D structure of soil pores and aggregates. Although some techniques, including thin sectioning [4,

(C) Institute of Molecular Biology and Genetics, NAS of Ukraine, 2011
5], the physical isolation of individual soil aggregates [6], the use of sampling tubes [7] and micro-sampling rods [8] allow investigation of microbial communities at the micro-scale, we suggest that a modern development of the classical buried slide method [9] could provide a means of sampling soil communities in a manner in which spatial distributions are retained, and is also compatible with modern molecular methods.

Nikolay Cholodny famously developed the buried glass slide method to sample soil microorganisms almost a century ago in Kiev. This and similar methods are largely forgotten today as focus shifted to the use of 
molecular techniques to investigate microbial diversity and activity. He buried slides for extended periods before recovery and microscopic examination of the adhered soil particles and associated microflora. Both fungi and bacteria were seen to colonize the glass surface from soil particles, and regions of poor colonization corresponding to hollows (i. e. pores) where «the particles of soil do not lie close to the slide surface» (pg. 150 in [10]).

Cholodny recognized that the glass surface which, due to its hydrophilic nature, was covered in a thin film of water that would allow the movement of bacteria and the diffusion of nutrients. The «surface effect» of artificial structures such as sampling devices and containers is often regarded as problematic since it may bias the development of fungal hyphae and plant roots. However, this problem is ameliorated as the size of the structure is reduced: soil microcosms are often produced using sieved soil with aggregate and particle sizes of $<2 \mathrm{~mm}$, which suggests that samplers of this dimension should be employed rather than the $70 \times$ $\times 35 \mathrm{~mm}$ glass slides used by Cholodny. Unlike glass, plastic films, e. g. PET (polyethylene terephtalate), are readily cut to size and are also suitable for microscopy. The adherence of some bacterial pathogens to the hydrophobic PET film surface has been investigated [1113], but as yet the attachment of soil bacteria to this material has not been examined.

Advances in micro-focus X-ray computed tomography $(\mu \mathrm{CT})$ allow the internal 3D structure of soil to be non-destructively imaged at a resolution of $\sim 10 \mu \mathrm{m}$ [14]. $\mu \mathrm{CT}$-determined pore networks can then be used as the basis for modelling water distribution, nutrient and oxygen gradients etc., in a way that describes microbial habitats at the micro-scale and predicts community activity and soil function [14]. Although the threshholding (binary segmentation) of $\mu \mathrm{CT}$ images into pore space and solids is problematic [15], it may be possible to identify PET films in situ in soil microcosms using this technique, and then to map the points of soil contact across the surface of the film to visualise Cholodny's «hollows» and other spatial features. Such 3D information could then be combined with film-based microscopical analyses of microbial distribution, diversity and activity to produce a better understanding of soil micro-habitats.
In this report, we investigate whether PET films can be used as a modern development of Cholodny's buried slides, and whether they can be visualised in soil with respect to local 3D pore structure by $\mu \mathrm{CT}$ imaging.

Materials and methods. Bacteria and culturing conditions. Wild-type Pseudomonas fluorescens SBW25 [16] and P. putida KT2440 [19] were used in this work, as well as the two P. fluorescens SBW25 mutants, $\Delta v i s c A$ [17] and WS-GFP [18]. Pseudomonads were cultured using KB (King's B) medium [20] at $18-20^{\circ} \mathrm{C}$.

WS-GFP biofilms were produced in statically (i. e. vibration-free) incubated KB cultures [21]. Inocula for experiments were provided by cells from over-night cultures re-suspended in PBS.

PET films and assays. Pieces of PET film were cut from $40 \mu \mathrm{m}$ - or $310 \mu \mathrm{m}$-thick sheets and sterilized by autoclaving (for the thin films) or with ethanol (thick films). Aliquots of bacterial suspension were placed onto $1 \mathrm{~cm}^{2}$ pieces of PET film incubated for 1-4 h. Unattached bacteria were removed by rinsing twice in sterile deionised water (hereafter «water»). Films were stained with $0.05 \%(\mathrm{w} / \mathrm{v})$ Crystal violet $(\mathrm{CV})$ for $3 \mathrm{~min}$ before rinsing twice in water. $\mathrm{CV}$ was then eluted in $1 \mathrm{ml} 96 \%$ ethanol for $1 \mathrm{~h}$ before absorbance $\left(\mathrm{OD}_{570}\right)$ was measured to determine the level of attachment (or detachment). A Kruss K100 Mk2 Tensiometer was used to measure liquid surface tension of cell-free culture supernatants, produced after the centrifugation of stationary phase $(18 \mathrm{~h}) \mathrm{KB}$ cultures at 3,220 $\mathrm{g}$ for $10 \mathrm{~min}$, as described previously [18]. Data is reported as the mean \pm standard error (SE). Differences between means was determined by Student's $t$-test assuming unequal variances.

$P C R$. Pieces of PET film $\left(0.25 \mathrm{~cm}^{2}\right)$ were cut into 4-5 fragments and added to $25 \mu 1$ PCR reactions mixtures (Taq PCR Kit, «New England Biolabs») containing universal $16 \mathrm{~S}$ primers (uni-for: 5'-TGC CAG CAG CCG CGG TA-3' and uni-rev: 5'-GAC GGG CGG TGT GTA CAA-3') [22]. These were amplified after 6 min at $95^{\circ} \mathrm{C}$ by 28 cycles of $30 \mathrm{~s}$ at $95^{\circ} \mathrm{C}, 30 \mathrm{~s}$ at $57.1^{\circ} \mathrm{C}$ and $30 \mathrm{~s}$ at $70^{\circ} \mathrm{C}$. Purified genomic DNA was used as a positive control. The PCR products were visualised by $1.2 \%$ agarose-TBE gel electrophoresis after EtBr staining. 
Soil microcosms and filtered soil suspension. Bullion field soil from the Scottish Crop Research Institute (Invergowrie, UK) [23] was air-dried and sieved to obtain $<2 \mathrm{~mm}$ sized aggregates. Soil microcosms were produced by packing soil with PET films into plastic rings to a density of $1.3 \mathrm{~g} / \mathrm{cm}^{3}$ (microcosms are artificial or simplified environments used to investigate aspects of ecology; typically they are small and easily manipulated for experimentation). These were saturated with water and then equilibrated to $-8 \mathrm{kPa}$ on a tension table before incubation in a plastic box to reduce evaporation for 7 days. Aliquots of soil, and PET films recovered from microcosms washed twice in water, were shaken in $2 \mathrm{ml}$ PBS for $2 \mathrm{~h}$ before dilution and spreading onto KB plates.

A filtered soil suspension was prepared by shaking $0.5 \mathrm{~g}$ soil in $6 \mathrm{ml}$ water for $24 \mathrm{~h}$ before filtration through a $0.55 \mu \mathrm{m}$ membrane.

Microscopy. PET films were fixed by exposure to formalin or gluteraldehyde vapour for $30 \mathrm{~min}$ (except the $P$. fluorescens SBW25 WS-GFP biofilms which were not fixed), then stained with $5 \mu \mathrm{g} / \mathrm{ml}$ Acridine orange (AO), $5 \mu \mathrm{g} / \mathrm{ml}$ Calcofluor, $2 \mu \mathrm{g} / \mathrm{ml}$ Ethidium bromide (EtBr), $5 \mu \mathrm{g} / \mathrm{ml}$ Hoechst 33342, and/or $5 \mu \mathrm{g} /$ $\mathrm{ml}$ Propidium iodide (PI) for 3-5 $\mathrm{min}$ (90 $\mathrm{min}$ for Hoechst) before washing with water and the addition of antibleach reagent (para-phenylendiamine) [24]. Films were then placed onto conventional microscope slides and covered with a slip before CLSM (confocal laser scanning microscopy).

$\mu C T$ imaging. A representative soil microcosm containing PET films was imaged using a Nikon Metrology micro-focus X-ray $\mu \mathrm{CT}$ system at $90 \mathrm{kV}, 138 \mu \mathrm{A}$, with 3,000 angular projections at 1 frame per second and a detector resolution giving a sample voxel resolution of $24.9 \mu \mathrm{m}$. Radiographs were reconstructed as a 3D volume using CTAgent/CTPro («Nikon», Japan), imported into VGStudio Max (http://www.volumegraphics.com/) for inspection and exported as JPEG files.

Results and discussion. In order to examine the utility of PET film samplers for soil and rhizosphere studies, we first investigated the ability of two model soil and plant-associated pseudomonads, $P$. fluorescens SBW25 [16] and P. putida KT2440 [19] to attach and detach from PET films. Preliminary CV staining experiments showed that both bacteria clearly adhered

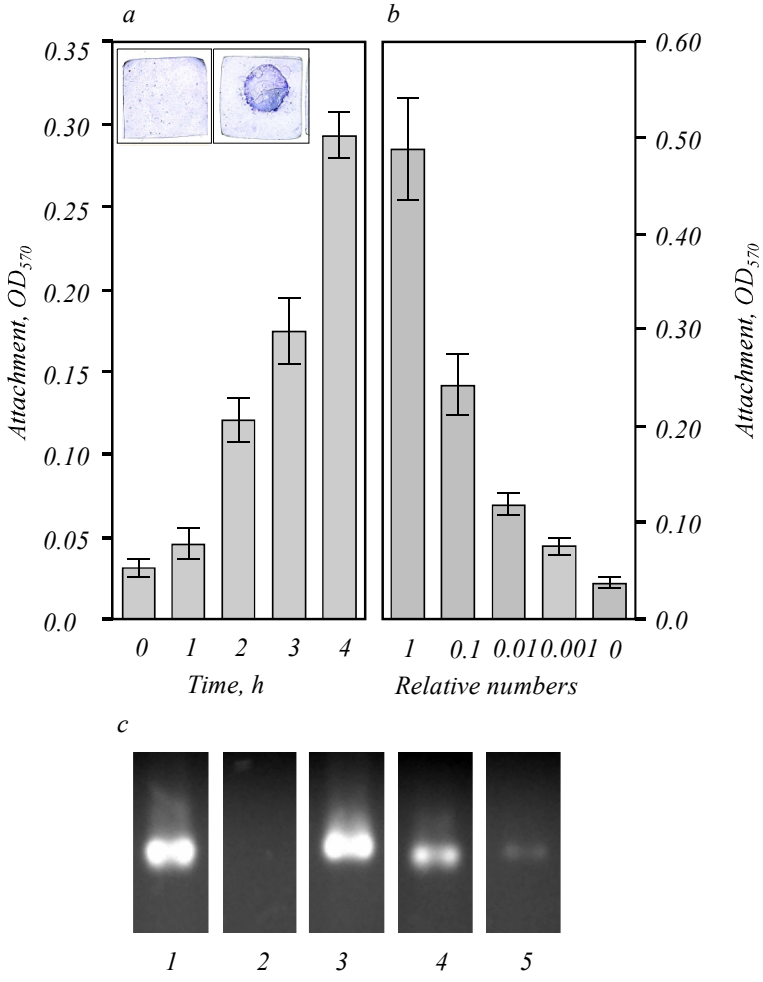

Fig. 1. P. putida KT2440 cells are able to attach to PET films. Bacterial attachment levels, determined by Crystal violet (CV) staining $\left(\mathrm{OD}_{570}\right)$, increases with incubation time and with cell numbers: $a-$ attachment levels after $4 \mathrm{~h}$ incubation were $\sim 6 \times$ greater than that seen after only $1 \mathrm{~h}$ incubation (the bacterial suspension was a $0.01 \times$ dilution of $P$. putida KT2440 cells in PBS; the inset shows two pieces of film stained with CV after incubation with PBS (left) and P. putida KT2440 suspension (right)); $b$ - attachment levels decrease with increasing dilution of the bacterial suspension $(1-0.001 \times$ dilutions of $P$. putida KT2440 suspensions were allowed to attach for $2 \mathrm{~h}$ before assay); $c-$ DNA sequences can be directly amplified from $P$. putida KT2440 attached to PET films. Shown are the results of PCR amplifications of genomic DNA control (1); a sample of sterile film (2); a sample with attached bacteria (3); a sample with attached bacteria after drying (4); and a sample with attached bacteria after fixation (5)

to this novel hydrophobic substrate ( $P$. fluorescens SBW25 has already been reported to attach to hydrophilic surfaces such as glass, e. g. [18]; P. putida KT2440 is known to attach to a range of surfaces including glass [25]). Bacterial attachment could be quantified by $\mathrm{CV}$ measurements as shown in Fig. 1, demonstrating that $P$. putida KT2440 attachment to PET films increased with incubation time and cell numbers (similar results were observed using $P$. fluorescens SBW25, data not shown). P. putida KT2440 attachment levels were $\sim 3 \times$ higher when cells were re-suspended in KB rather than PBS, suggesting that bacterial attachment to 
PET film surfaces was sensitive to chemical conditions. This attachment was clearly reversible, as $P$. puti$d a$ KT2440 cells detached from PET films when shaken in PBS, with a $10 \%$ decrease in CV levels observed after $1 \mathrm{~h}$ and a $30 \%$ decrease after $4 \mathrm{hr}$ incubation. These observations suggest that other soil and plant-associated bacteria could be expected to attach to PET films, as is the case for a variety of medically-important pathogens.

As a simple demonstration that PET films are likely to be compatible with modern molecular techniques, we have shown the results of PCR amplifications of DNA from bacteria attached to PET films in Fig. 1, $c$.

Bacterial surface attachment involves a range of interactions dependent on cell and substrate surface chemistry [26]. For example, Campylobacter jejuni and Mycobacterium avium have different cell surface properties which effect attachment to PET [12], whilst modification of the surface chemistry of PET reduces the attachment of Staphylococcus epidermis $[11,13]$. Similar studies have not been undertaken with soil and plant-associated bacteria which might be expected to bind to a wider range of substrates under different conditions than these pathogens.

Modification or pre-treatment of surfaces to produce a «conditioning film» with altered physicochemical properties can have a significant impact on bacterial attachment and colonisation [26]. To examine whether P. fluorescens SBW25 and P. putida KT2440 attachment was sensitive to altered PET surface chemistry, we compared attachment to clean PET film and samples that had been pre-treated with PBS, cell-free culture supernatants or filtered soil suspension.

Pre-treatment with PBS had no significant impact on attachment $(\mathrm{P}=0.8732)$, suggesting that a phosphate and saline (pH 7.4) solution did little to modify the surface chemistry of the PET film. Similarly, pretreatment with a mixture of bacterially-derived components present in a cell-free $P$. fluorescens SBW25 culture supernatant, resulted in a small increase in attachment $(2 \times ; \mathrm{P}=0.0078)$, suggesting that some of these components might interact with the film surface to provide a better attachment site for bacteria. Interestingly, pre-treatment with a cell-free culture supernatant derived from the $P$. fluorescens SBW25 $\Delta v i s c A$ mutant unable to produce the surfactant viscosin, resul- ted in significantly higher levels of attachment $(8 x ; \mathrm{P}=$ $=0.0001)$. The presence of viscosin was confirmed in the wild-type supernatant and not in the mutant supernatant, by surface tension measurements $(25.61 \pm 0.14$ and $49.19 \pm 0.14 \mathrm{mN} \cdot \mathrm{m}^{-1}$, respectively; $\left.\mathrm{P}<0.0001\right)$. This suggests that viscosin interacts with the PET film surface and reduces bacterial attachment. Finally, pretreatment with a filtered soil suspension resulted in significantly higher levels of attachment $(9 \times ; \mathrm{P}=$ $=0.0001)$, indicating that soil-soluble components such as salts, clay, organic material and small particulate matter interact with the film to provide a surface environment more suitable for bacterial attachment. The impact of pre-treatment with a filtered soil suspension seen here suggests that artificial surfaces with a variety of surface chemistries may be rapidly improved for bacterial adhesion once covered by appropriate environmental chemicals and particulate matter.

If PET films are to be used to sample soil and rhizosphere microbial communities, bacteria must be able to colonise the PET film after initial attachment. Preliminary experiments suggest that this is possible, as $P$. putida KT2440 cells detached from PET films by shaking in PBS were still viable and produced colonies when spread onto KB plates. Colonies could also develop from PET films directly placed onto or embedded in the surface of agar plates.

In order to determine whether the growth of attached bacteria was inhibited by the physicochemical properties of PET, films were tested as a substrate for $P$. fluorescens SBW25 WS-GFP biofilm formation. The WS mutant of $P$. fluorescens SBW25 produces a cellulose-matrix-based air-liquid (A-L) interface biofilm which develops from bacteria attached to the glass walls of static liquid microcosms at the meniscus, and ultimately extends out to cover the entire A-L interface $[21,27]$. CLSM of PET films recovered from static microcosms showed clear evidence of $P$. fluorescens SBW25 WS-GFP biofilm development (Fig. 2, see inset), indicating that growth was not inhibited by the PET film surface. The growth of attached bacteria is generally influenced more by the physicochemical surface properties of the substrate than the initial attachment levels [26, 28].

The fact that bacteria such as $P$. fluorescens SBW25 and P. putida KT2440 can attach to, colonise 

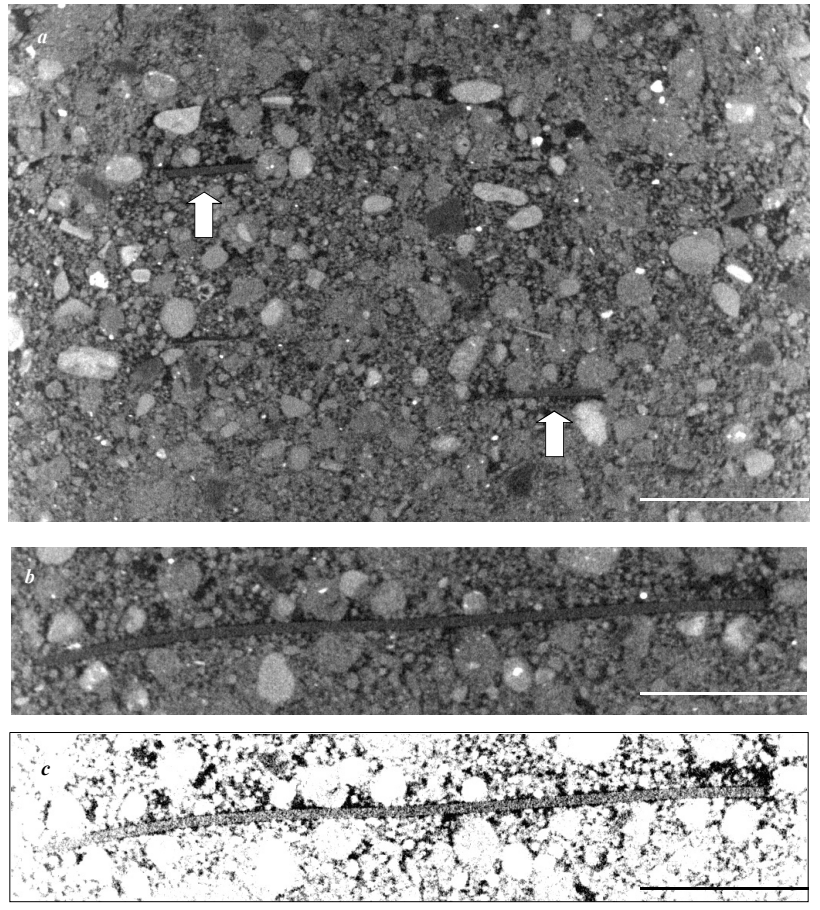

Fig 4. Buried PET films can be imaged in situ by $\mu \mathrm{CT}$. Nondestructive imaging of soil microcosms by $\mu \mathrm{CT}$ can locate the position of buried PET films with respect to local soil aggregate and pore structures. Shown are sagittal views of a soil microcosm containing two small $(a)$ and one long $(b)$ pieces of film. The grey-scale values of the image provided in $b$ have been arbitrarily adjusted to show how the pore spaces (black) are in intimate connection with the buried film in $(c)$. The scale bar indicates $1 \mathrm{~cm}$

the surface and detach from PET films under artificial conditions suggests that this novel substrate may prove to be a successful means of sampling microbial communities from soil and rhizosphere environments.

Preliminary CV-staining experiments suggested that soil bacteria colonise PET films with a $\sim 4 \times$ increase in CV staining after 3 days incubation in soil microcosms. However, this observation may be confounded by $\mathrm{CV}$ binding to other organic components adhering to the film in addition to at tached bacterial cells. Colonisation of PET films in soil by resident bacteria was subsequently demonstrated by recovering Pseudomonas spp. from soil microcosms by plating onto $\mathrm{KB}$ agar. These contained $\sim 710^{6} \mathrm{CFU}$ (colony forming units) per gram of soil, and between $1-2 \cdot 10^{6} \mathrm{CFU}$ could be recovered using PET films of $1 \mathrm{~cm}^{2}$. Pseudomonas cold also be recovered from 1-2 mm wide PET film strips by embedding in KB agar. Colonization of PET films by soil microorganisms was also examined by direct visualisation of PET films by fluorescent microscopy and CLSM; four examples of CLSM images are shown in Fig. 3 (see inset). Clumps of material, possibly consisting of fungal hyphae and soil detritus with associated bacteria, could be observed after staining with EtBr and AO. Bacterial colonization of the PET film, hyphae and detritus surfaces could also be observed using a combination of natural fluorescence, $\mathrm{AO}$ and Hoechst. The appearance of chains of cocci and arrays of bacillus suggest replication had occurred during the incubation of the films in the soil microcosms. The visualisation of both cocci and bacillus forms within aggregations also indicates that some spatial associations were retained at the scale of microbial habitats.

In order to determine whether the contacts between soil aggregates and the surface of PET film could be visualised in situ, we used $\mu \mathrm{CT}$ to investigate soil containing films. Typically, X-ray energies, filters and image capture settings are balanced to obtain the best differentiation of X-ray dense (e. g. mineral, sand and stone particles), intermediate (soil aggregates and water) and light (air-filled pores) materials. For this work, we used preliminary scans of a microcosm with a protruding piece of PET film to decide on an X-ray energy of $90 \mathrm{kV}$ and the use of a $0.25 \mathrm{~mm}$ aluminium filter. We have shown two sagittal views of a soil microcosm in Fig. 4 in which films are clearly identified (though such images are normally inspected as 3D structures). From the modified image in Fig. 4, $c$, it is clear that the surface of the film is intimately connected to the pore space of the surrounding soil, and gives an indication of how this technique could be extended to map the contact points between the film surface and soil aggregates.

Conclusions. The introduction of the buried slide technique by Cholodny in 1930 heralded the investigation of soil microbiology by microscopy. Eight decades later, there is a growing need to examine soils at the microbial scale, using techniques which retain spatial information that can be used to assess microbial interactions in a highly heterogeneous physical environment. In this report, we demonstrate that PET films are a successful development of Cholodony's microscope slides, allowing the sampling of natural microbial communities from soils. Fixing films for microscopy and 
preliminary PCR experiments suggest that these may be compatible with FISH (fluorescent in situ hybrdization) and other molecular techniques which may allow taxonomic identification and gene-expression analysis of soil communities, while parallel tests have already demonstrated that PET films can be used to recover bacteria from the rapeseed rhizosphere [29]. In the future, $\mu \mathrm{CT}$-derived maps of soil aggregate contact points and pore spaces across the surface of PET films might be combined with post-recovery microscopical analyses to enable a better understanding of soil microhabitats and the spatially-explicit nature of microbial interactions in this complex environment.

Acknowledgments. Some of the work presented here was undertaken by OE during a visit to the SIMBIOS Centre. We thank W. Otten for his help with the $\mu \mathrm{CT}$. AS is funded by the University of Abertay Dundee and is a member of the Scottish Alliance for Geoscience Environment and Society (SAGES). AK is a SAGES-associated $\mathrm{PhD}$ student. The University of Abertay Dundee is a charity registered in Scotland, No: SC016040.

О. В. Мошинець, А. Коза, П. Дело Стерпайо, В. А. Кордюм, Е. Д. Спайрс

Модифікація методу Холодного із застосуванням ПЕТ плівок для відбору зразків мікробних ценозів у грунті

\section{Резюме}

Мета иієї роботи полягала у дослідженні можливості використання плівок, виготовлених із ПЕТ (поліетилентетрафталат), як модифікації методу скелець обростання Холодного для мікроскопічного і молекулярно-генетичного аналізу трунтових спільнот із збереженням їхньої просторової архітектури на мікрорівні. Таке збереження деталей просторового розташування об'єктів дозволило б глибще вивчити їх у подібних складних середовищах проживання. Методи. Класичні мікробіологічні методи; аналіз прикріплення; вимірювання поверхневого натягнення; молекулярно-генетичні методи: екстракиія ДНК, ПЛР; конфокальна лазерна скануюча мікроскопія (КЛСМ); мікрофокусна рентгенівська комп'ютерна томографія (мікроКТ). Результати. По-перше, використовуючи модельні трунтові і ризосферні бакmepiï Pseudomonas fluorescens SBW25 i P. putida KT2440, ми показали, що бактерії здатні до прикріплення $і$ відкріплення від ПЕТ плівок, а прекультивачія за умов відфільтрованої трунтової суспензії покращує рівень прикріплення. Бактерії, які прикріпилися до плівок, зберігають свою життєздатність $і$ спроможні до формування повночінної біоплівки. ПЕТ плівки, занурені в трунт, колонізуються мікроорганізмами, що спостерігали як за допомогою КЛСМ, так і методом культивування ПЕТ плівок, видалених з трунту, на агаризованому поживному середовищі. По-друге, ми продемонстрували, що мікроКТ можна використовувати для неруйнівного спостереження сайтів зв'язування трунтових агрегатів і трунтових пор з поверхнею плівки, щьо перебуває в трунті.
Висновки. Застосування ПЕТ плівок виявилося вдалою модифікаиією методу скелець обростання Холодного та може бути корисним для відбору трунтових мікробних спільнот, дослідження бактерійного прикріплення, росту і розвитку як біоплівок, так $i$ спільноти. Використання цих плівок при аналізі трунтів за допомогою мікроКТ дозволить краще визначити трунтові мікроеконіші і природу архітектури мікробних взаємодій за таких складних екологічних умов.

Ключові слова: Pseudomonas, tрунт, скельия обростання, ПЕТ плівки.

\section{Е. В. Мошинеи, А. Коза, П. Делло Стерпайо, В. А. Кордюм,}

Э. Д. Спайрс

Модификация метода Холодного с применением ПЭТ пленок для отбора образцов микробных ценозов в почве.

Резюме

Цель данной работы состояла в исследовании возможности использования пленок, изготовленных из ПЭТ (полиэтилентерефталат), как современной модификации метода стекол обрастаний Холодного для микроскопического и молекулярно-генетического анализа почвенных сообществ с сохранением их пространственной архитектуры на микроуровне. Такая сохранность деталей пространственного расположения объектов позволила бы глубже изучить их в подобных сложных условиях обитания. Методы. Классические микробиологические методы; анализ прикрепления; измерение поверхностного натяжения; молекулярногенетические методы: экстракция ДНК, ПЦР; конфокальная лазерная сканирующая микроскопия (КЛСМ); микрофокусная рентгеновская компьютерная томография (микроКТ). Результаты. Во-первых, используя модельные почвенные и ризосферные бактерии Pseudomonas fluorescens SBW25 u P. putida KT2440, $\mathrm{Mbl}$ показали, что бактерии способны к прикреплению и откреплению от ПЭТ пленок, а прекультивирование в условиях отфильтрованной почвенной суспензии улучшает уровень прикрепления. Бактерии, прикреп- ленные к пленкам, сохраняют жизнеспособность и могут формировать полноценную биопленку. ПЕТ пленки, погруженные в почву, колонизируются микроорганизмами, что наблюдали как с применением КЛСМ, так и методом культивирования извлеченных из почвы пленок на агаризованной питательной среде. Во-вторых, мы продемонстрировали, что микроКТ можно использоватьа для недеструктивного наблюдения за сайтами связывания почвенных агрегатов и почвенных пор с поверхностью ПЕТ пленки, находящейся в почве. Выводы. Применение ПЕТ пленок оказалось удачной модификаиией метода стекол обрастаний Холодного и может стать полезным для отбора почвенных микробных сообществ, изучения бактериального прикрепления, роста, развития как биопленок, так и сообщества. Использование этих пленок при анализе почвы с помощью микроКТ позволит лучше определять почвенные микроэкониши и природу архитектуры микробных взаимодействий в таких сложных экологических условиях.

Ключевые слова: Pseudomonas, почва, стекла обрастания, ПЭТ пленки.

\section{REFERENCES}

1. Compant S., Duffy B., Nowak J., Clement C., Barka E. A. Use of plant growth-promoting bacteria for biocontrol of plant diseases: principles, mechanisms of action, and future prospects // Appl. Environ. Microbiol.-2005.-71, N 9.-P. 4951-4959. 
2. Compant S., Clement C., Sessitsch A. Plant growth-promoting bacteria in the rhizo- and endosphere of plants: their role, colonization, mechanisms involved and prospects for utilization // Soil Biol. Biochem.-2010.-42, N 5.-P. 669-678.

3. Dubey S. K., Tripathi A. K., Upadhyay S. N. Exploration of soil bacteria communities for their potential as bioresource // Bioresour. Technol.-2006.-97, N 17.-P. 2217-2224.

4. Fisk A. C., Murphy S. L., Tate R. L. Microscopic observations of bacterial sorption in soil cores // Biol. Fertility Soils.-1999.-28, N 2.-P. 111-116

5. Li Y., Dick W. A., Tuovinen O. H. Evaluation of fluorochromes for imaging bacteria in soil // Soil Biol. Biochem.-2003.-35, N 6.-P. 737-744.

6. Kabir M., Chotte J. L., Rahman M., Bally R., Monrozies L. J. Distribution of soil fractions and location of soil bacteria in a vertisol under cultivation and perennial grass // Plant Soil.1994.-163, N 2.-P. 243-255.

7. Gilmore A. E. A soil sampling tube for soil microbiology // Soil Sci.-1959.-87, N 2.-P. 95-99.

8. Dennis P. G., Miller A. J., Clark I. M., Taylor R. G., Valsami-Jones E., Hirsch P. R. A novel method for sampling bacteria on plant root and soil surfaces at the microhabitat scale // J. Microbiol. Meth.-2008.-75, N 1.-P. 12-18.

9. Cholodny N. Uber eine neue Methode zur Untersuchung der Bodenmikroflora // Arch. Microbiol.-1930.-1, N 1.-P. 620-652.

10. Cholodny N. G. A soil chamber as a method for the microscopic study of the soil microflora // Arch. Microbiol.-1934.-5, N 1.P. 148-156.

11. MacKintosh E. E., Patel J. D., Marchant R. E., Anderson J. M. Effects of biomaterial surface chemistry on the adhesion and biofilm formation of Staphylococcus epidermidis in vitro // J. Biomed. Mater. Res.-2006.-78, N 4.-P. 836-842.

12. Tatchou-Nyamsi-Konig J. A., Dague E., Mullet M., Duval J. F., Gaboriaud F., Block J. C. Adhesion of Campylobacter jejuni and Mycobacterium avium onto polyethylene terephtalate (PET) used for bottled waters // Water Res.-2008.-42, N 19.-P. 47514760 .

13. Wang J., Huang N., Yang P., Leng Y. X., Sun H., Liu Z. Y., Chu $P$. $K$. The effects of amorphous carbon films deposited on polyethylene terephthalate on bacterial adhesion // Biomaterials.2004.- 25, N 16.-P. 3163-3170.

14. O'Donnell A. G., Young I. M., Rushton S. P., Shirley M. D., Crawford J. W. Visualization, modelling and prediction in soil microbiology // Nat. Rev. Microbiol.-2007.-5, N 9.-P. 689699.

15. Baveye P. C., Laba M., Otten W., Bouckaert, L., Dello Sterpaio P., Goswami R. R., Grinev D., Houston A., Hu Y., Liu J., Mooney S., Pajor R., Sleutel S., Tarquis A., Wang W., Wei Q., Sezgin $M$. Observer-dependent variability of the thresholding step in the quantitative analysis of soil images and X-ray microtomography data // Geoderma.-2010.-157, N 1-2.-P. 51-63.

16. Rainey P. B., Bailey M. J. Physical and genetic map of the Pseudomonas fluorescens SBW25 chromosome // Mol. Microbiol.1996.-19, N 3.-P. 521-533.

17. De Brujin I., de Kock M. J., Yang M., de Waard P., van Beek T. A., Raaijmakers J. M. Genome-based discovery, structure prediction and functional analysis of cyclic lipopeptide antibiotics in Pseudomonas species // Mol. Microbiol.-2007.-63, N 2.P. 417-428.

18. Koza A., Hallett P. D., Moon C. D., Spiers A. J. Characterization of a novel air-liquid interface biofilm of Pseudomonas fluorescens SBW25 // Microbiology.-2009.-155, Pt 5.-P. 1397-1406.

19. Nelson K. E., Weinel C., Paulsen I. T., Dodson R. J., Hilbert H., Martins dos Santos V. A., Fouts D. E., Gill S. R., Pop M., Holmes M., Brinkac L., Beanan M., DeBoy R. T., Daugherty S., Kolonay J., Madupu R., Nelson W., White O., Peterson J., Khouri H., Hance I., Chris Lee P., Holtzapple E., Scanlan D., Tran K., Moazzez A., Utterback T., Rizzo M., Lee K., Kosack D., Moestl D., Wedler H., Lauber J., Stjepandic D., Hoheisel J., Straetz M., Heim S., Kiewitz C., Eisen J. A., Timmis K. N., Dusterhoft A., Tummler B., Fraser C. M. Complete genome sequence and comparative analysis of the metabolically versatile Pseudomonas putida KT2440 // Environ. Microbiol.-2002.-4, N 12.-P. 799808 .

20. King E. O., Ward M. K., Raney D. E. Two simple media for the demonstration of pyocyanin and fluorescin // J. Lab. Clin. Med.-1954.-44, N 2.-P. 301-307.

21. Spiers A. J., Kahn S. G., Bohannon J., Travisano M., Rainey P. $B$. Adaptive divergence in experimental populations of Pseudomonas fluorescens. I. Genetic and phenotypic bases of wrinkly spreader fitness // Genetics.-2002.-161, N 1.-P. 33-46.

22. Widmer F., Seidler R. J., Gillevet P. M., Watrud L. S., Di Giovanni $G$. D. A highly selective PCR protocol for detecting $16 \mathrm{~S}$ rRNA genes of the genus Pseudomonas (sensu stricto) in environmental samples // Appl. Environ. Microbiol.-1998.-64, N 7.-P. 2545-2553.

23. Hallett P. D., Young I. M. Changes to water repellence of soil aggregates caused by substrate-induced microbial activity // Eur. J. Soil Sci.-1999.-50, N 1.-P. 35-40.

24. Johnson G. D., Nogueira Araujo G. M. A simple method of reducing the fading of immunofluorescence during microscopy // J. Immunol. Meth.-1981.-43, N 3.-P. 349-350.

25. Espinosa-Urgel M., Salido A., Ramos J. L. Genetic analysis of functions involved in adhesion of Pseudomonas putida to seeds // J. Bacteriol.-2000.-182, N 9.-P. 2363-2369.

26. Bos R., van der Mei H. C., Busscher H. J. Physico-chemistry of initial microbial adhesive interactions - its mechanisms and methods for study // FEMS Microbiol. Rev.-1999.-23, N 2.P. 179-230.

27. Bantinaki E., Kassen R., Knight C. G., Robinson Z., Spiers A. J., Rainey $P$. B. Adaptive divergence in experimental populations of Pseudomonas fluorescens. III. Mutational origins of wrinkly spreader diversity // Genetics.-2007.-176, N 1.-P. 441-453.

28. Gottenbos B., Van der Mei H. C., Busscher H. J. Initial adhesion and surface growth of Staphylococcus epidermidis and Pseudomonas aeruginosa on biomedical polymers // J. Biomed. Mater. Res.- 2000.-50, N 2.-P. 208-214.

29. Moshynets O. V., Shpylova S. P., Spiers A. J., Kosakivska I. V. The phytosphere of Brassica napus L. as a niche for Pseudomonas fluorescens SBW25 // Rep. Natl Acad. Sci. Ukraine.2010.-N 12.- P. 150-153.

UDC $579.262+57.083 .1$

Received 26.11 .10 
Figures to article by $O . V$. Moshynets et al.

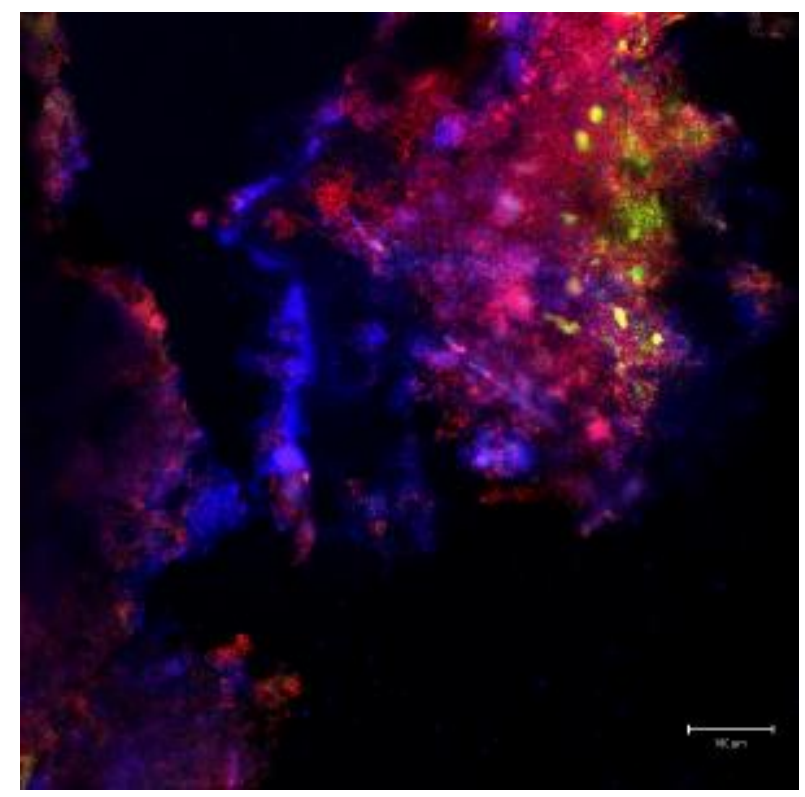

Fig. 2. PET films supported the development of WS-GFP biofilms. Film pieces positioned to pierce the A-L interface of static liquid microcosms were colonised by WS-GFP and developed biofilms. Shown here is a micro-colony with associated cellulose imaged by CLSM where active WSGFP cells are green, PI-stained dead cells are red, and Calcofluor-stained cellulose is blue. The scale bar indicates $100 \mu \mathrm{m}$
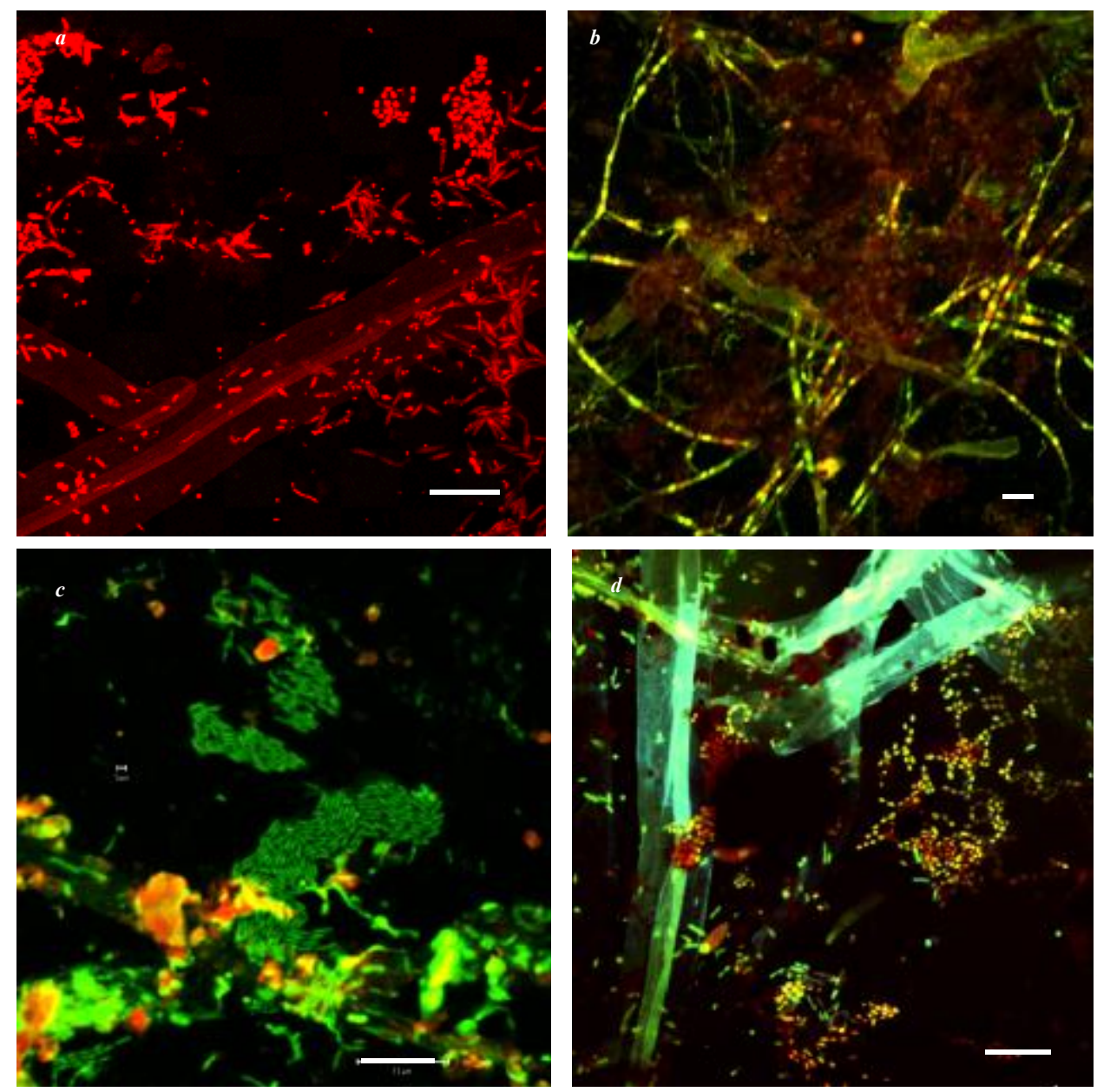

Fig. 3. Soil microbial communities on PET films are readily imaged by fluorescent microscopy. Films recovered from soil microcosms can be imaged by CLSM after staining with (a) EtBr and (b) $\mathrm{AO}$ to reveal microbial colonisation of the PET film surface and adhering soil particles. More complex images are shown in $(c)$ and $(d)$ using a combination of natural fluorescence, $\mathrm{AO}$ and Hoechst. The scale bars indicate $10 \mu \mathrm{m}$ 